\title{
Innovation in Modelling of Flood-Friendly Housing Design with approaching of Sundanese Traditional Architecture (Case Study: Baleendah Sub-District, Bandung District, West Java-Indonesia)
}

\author{
Nuryanto $^{1}$, R. Irawan Surasetja ${ }^{2}$, and Dadang Ahdiat ${ }^{3}$ \\ ${ }^{1}$ Departemen of Architecture, Universitas Pendidikan Indonesia, Bandung City, Indonesia \\ nuryanto_adhi@upi.edu \\ ${ }^{2}$ Departemen of Architecture, Universitas Pendidikan Indonesia, Bandung City, Indonesia \\ irawansurasetja@upi.edu \\ ${ }^{3}$ Departemen of Architecture, Universitas Pendidikan Indonesia, Bandung City, Indonesia \\ dadangahdiat@upi.edu
}

\begin{abstract}
The research locations are Cieunteung residence in Babakan Mekarsari village and Jambatan village in Andir, Baleendah sub-district, Bandung District-West Java Province in Indonesia. The prototype for flood-friendly houses in villages that will be proposed to the local government. The research gives two important formulas, there are: (1) Concept design of the floodfriendly house with Sundanese architecture approaTches (imah panggung) (2) The design of a flood-friendly housing includes: the design of the floor plan, the design of house facade, the design of roof and the design of house structure and construction according to the local wisdom of Sundanese traditional architecture. Two important formulation results in the planning and designing the flood-friendly houses in the two villages will be submitted as the proposal to the local government as well as consideration to anticipate the wider impact of the flood.
\end{abstract}

Index Terms - : Inovation, House design, flood-freindly, Sundanese traditional architecture.

\section{INTRODUCTION}

$\mathrm{U}$ ntil now, flood disaster still left unresolved problem and cannot be dealt permanently both by the central government, regional government or even city government. Disaster handling is always temporary and was done by the locals who lived in flood-prone areas independently. For examples, the rich people were designed two storey houses intended to prevent a flood on the first floor and the owner can move to the second floor when the flood comes. On the other hand for the poor people, were evacuated to another family house or keep staying in their flooded houses. In the past, there is no flood-friendly house design yet to anticipate submerging the main part of the house. Though architecturally, the design concept of the flood-friendly house can be made for the local residents. These all problems above become the background of this research about "Innovation In Modelling of Flood-Friendly Housing Design With Approaching of Sundanese Traditional Architecture (Case Study in Baleendah Sub-district, Bandung Regency, West Java-Indonesia)". The reason for chosen Baleendah sub-district become the study area in this research because this area was affected by the most severe flooding in the last five years since 2010 [1]. The house's design is inspired by the local wisdom of Sundanese traditional architecture, especially the house on stilts. The local wisdom of Sundanese traditional architecture as approachment in this research because of the value of richness and uniqueness locality. The results of this research are expected as a solution to solve the flood disaster problems.

\section{LITERATURE REVIEW}

\section{a. Definition of Flood}

Flood is a condition where water is not accommodated in the drainage channel (river) or obstructed the flow of water in the drainage channel [2]. According to the Kamus Besar Bahasa Indonesia [3], the definition of flood consists of several criteria, namely (1) Based on the verb the flood is [v] heavy and heavy water, sometimes overflowing (at times etc.): because the rain continues-continuously, the river became banijr; (2) Based on the words the object of flooding 
is [n] water that is abundant and rushing; Flood: in the rainy season, the area is often hit, or Geo the event of the sinking of land (which is usually dry) due to increased water volume;

(4) Based on the adjective flood also means 'datang' (coming) or ' $a d a$ ' (there are) a lot, for example in the sentence: 'menjelang lebaran di pasar banjir petasan' (before Eid al-Fitr on the firecracker flood market). Based on these two definitions, it can be concluded that flooding is a condition or condition during the rainy season which causes rivers or water reservoirs to be mass unable to accommodate the amount of water, due to obstruction of water flow in the water collection channel, so that the water rises beyond the normal surface limit. Some characteristics related to flooding include: (1) Floods can come suddenly with great intensity but can flow immediately; (2) Floods come slowly but the intensity of the rain is little; (3) seasonal flood patterns; (4) Floods come slowly but can become a long puddle in depressed areas; (5) The resulting effect is inundation, erosion, and sedimentation. While other consequences are the isolation of residential areas and evacuation of the population is required [2].

\section{b. Factors Causing Flooding}

According to Kodoatie and Sugiyanto [4], there are many factors that cause flooding. But in general the causes of floods can be classified into 2 categories, namely floods caused by natural causes and floods caused by human actions, including: (1) Rainfall; In the rainy season, high rainfall will cause flooding in the river and if the flood exceeds the river bank, there will be flooding or inundation; (2) Effects of Physiography; Physical physiography or geography of the river such as the shape, function and slope of the river flowing area (Daerah Pengaliran Sungai or DPS), river slope, hydraulic geometric (cross-section shape such as width, depth, lengthwise cuts, river bed material), river location etc.; (3) Erosion and Sedimentation; Erosion and sedimentation in DPS affect the reduction in river crosssectional capacity. The amount of sedimentation will reduce channel capacity, resulting in inundation and flooding in rivers; (4) River capacity; Reduction in flood flow capacity in rivers can be caused by sedimentation originating from DPS erosion and river embankment erosion; (5) Inadequate Drainage Capacity; (6) The effect of the tides slowing the flow of the river into the sea.

\section{c. Sundanese Traditional of Architecture}

The types and patterns of villages in traditional architecture in Tatar Sunda (West Java Province) based on their geographical location are divided into three parts, namely: (1) Kampung pegunungan, namely villages located in mountainous and highland areas; (2) Kampung dataran rendah, namely villages located in lowland areas; (3) Kampung pesisir pantai, namely villages located on the coast, or along the coast [5]. According to Nix in Danumihardja [6], the characteristics of the Tatar Sunda natural environment also gave the idea of giving the name of the village, including galudra ngupuk, a village that is located between two hills or mountains; Pancuran emas is a village that is located right on the slope of a hill or mountain that is descending and facing southwest; Satria lalaku is a type of village on a slope of a hill or mountain that is descending and facing southeast; Kancah nangkub is a village that is located right on a hilltop; Gajah Palisungan is a type of village that is on a hilltop in a flat land condition; Bulan purnama is the village in the river valley; Gajah Katunan is a village located in the lowlands, surrounded by hills or sand [6].

The shape of Sundanese people's house is a stage, which is a house with a cage using a umpak or tatapakan foundation. According to Adimihardja and Salura [7], the form of the stage that dominates the building system in the Tatar Sunda has technical and symbolic functions. Technically, the stilt house has three functions, namely: do not disturb the field of water catchment, underneath as a space conditioning medium with crossing air flow both for warmth and coolness, and underneath is also used to store supplies of firewood and others. The symbolic function is based on the belief of the Sundanese, that the world is divided into three: ambu handap (the underworld), ambu luhur (the upper world), and ambu tengah (middle world). In mythology related to agriculture, Sundanese people highly respect Nyi Pohaci Sanghyang Sri, who is considered to be the embodiment of rice. Therefore, rice or rice is always stored properly in a special place called goah for rice and padaringan for rice. If there is a lot of rice, then to save it is provided leuit or granary [8].

\section{RESEARCH METHODOLOGY}

The method uses in this research is the descriptivequalitative method by way of describing in writing from the results of a field survey about the real condition of the area that has tourism potential. While the research method uses in this research is secondary data analysis methods obtained from relevant agencies and survey method (observation) with research that focuses on surveys supported by field observations to get data about planning and designing floodfriendly houses. The location of this study is located in floodprone area, among them is Cieunteung Village, Baleendah District, South Bandung Regency. The choice of location is based on several considerations, there are: (1) The area that was most affected by the floods in the past five years; (2) The location of the villages is very close to the Citarum and Cisangkuy Rivers; (3) The village is included in the list of flood-prone area and flood alert areas in the provincial or in district of BNPB. While the reasons for chosen Naga village and Baduy village as objects of comparative studies because of their diversity and the richness of their unique and typical traditional architecture [1].

\section{The Philosophy of a House Friendly to Floods}

According to Poerwadarminta [3] in the Kamus Besar Bahasa Indonesia (KBBI), it was mentioned that "friendly" (adjective) means kind, interesting language, sweet speech and nature, like to get along, friendly, and warm. From this understanding, it is most appropriate to provide an explanation of the meaning of "friendly" in the context of flooding. In English, friendly is called friendly; "Able to understand and follow and not damage" means to be able to understand and follow and not damage [9]. In the context of 
research on flood-friendly, friendly house can be interpreted as a specially designed house that is able to understand the needs of its inhabitants during the dry and rainy season (two functions), and does not damage the environment (friendly/harmony with the environment). A flood-friendly house has a dual function, during the rainy season residents move upstairs safely and comfortably, while during the dry season residents can do activities on the upper and lower floors.

\section{RESULT AND DISCUSSION}

\section{a. Description of Research Location}

Babakan Mekarsari Village, Cieunteung residence and Jembatan village are part of the administrative area of Baleendah District which is astronomically located at the coordinates $7^{\circ} 13^{\prime}-7^{\circ} 71^{\prime} \mathrm{LS}$ and $107^{\circ} 31^{\prime}-107^{\circ} 40^{\prime}$ BT. While geographically located in the middle of Bandung Regency area which borders on 5 other sub-districts (picture 3). The altitude of the region is at 600 meters above sea level up to 715 meters above sea level, most of which are low land area and hills with temperatures ranging from $24^{\circ}-32^{\circ}$ Celsius. The two villages were traversed by two large rivers, there are Citarum and Cisangkuy river. The climate in both villages is generally similar to other regions on the tropical island of Java, the rainy season and the dry season. During 2013-2014 the rainfall in Baleendah District was relatively low: 1,856 $\mathrm{mm}$ per year with an average of 10 rainy days per month. Baleendah District has an area of $34.18 \mathrm{~km} 2$, administratively divided into 8 villages or residence-level regions. Maps of location can to see at the below picture:
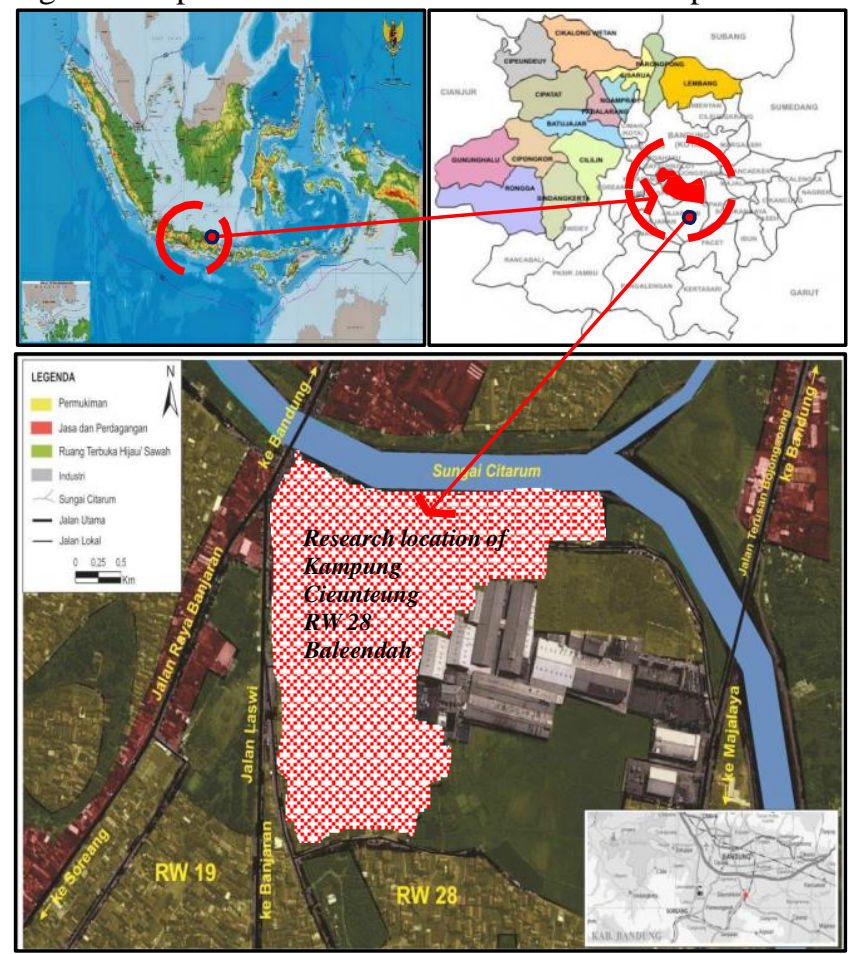

Fig. 1 Maps of location of research in Baleendah Disrict Source: Nuryanto, et al. [1]

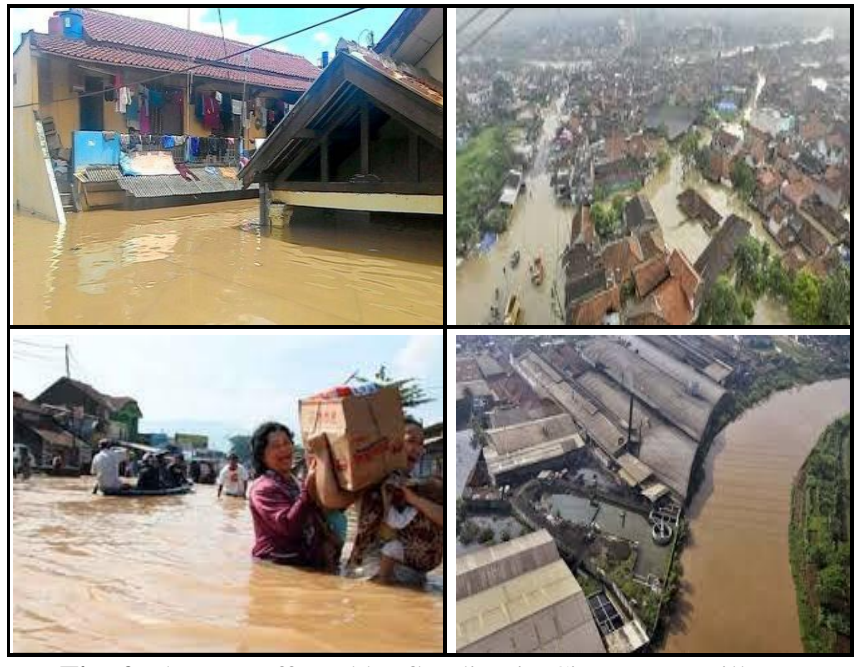

Fig. 2 The area affected by flooding in Cieunteung Village Source: Nuryanto, et al. [1]

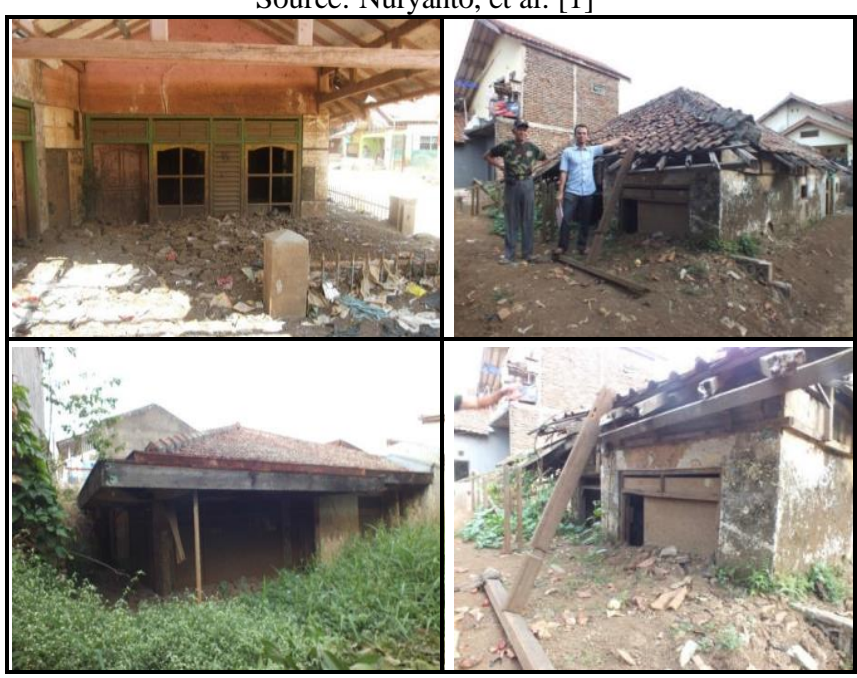

Fig. 3 Houses destroyed by floods in Cieunteung village Source: Nuryanto, et al. [1]

In Baleendah District, especially in Cieunteung area of Babakan Mekarsari village and Jambatan village under the flooding area. These villages are the densest area, with a population of 450 people and 283 families. Houses lined up very closely with each other, almost without ideal distance. Residential houses are connected by small roads or even just an alley that with wide between 1-1.2 meters. Whereas citizen access is connected by a highway with a wide width, between 3.8-4.5 meters. Very dense inter-house distance has implications for the comfort and safety of residents, especially during a flood. Flood elevation plan of the Citarum River and Cisangkuy river in this area is $+659,3$ above the sea level, while land elevation in this area is +658 above the sea level, so that when the big flood in February 2010 reached an elevation of 660.3 above the sea level, this area experienced the puddle of water as high as $2.3 \mathrm{~m}$. The residents in both villages were accustomed to being flooded by overflowing Citarum and Cisangkuy Rivers, which also affected other regions, such as Dayeuhkolot and its surroundings. In November $20^{\text {th }} 2014$ there was a major 
flood disaster in three sub-districts, in Baleendah, Dayeuhkolot, and Bojongsoang. The flood inundated as many as 3,000 houses in the three sub-districts. Many residents' houses were severely damaged. Hundreds of thousands of houses have been severely damaged by water (photo 6), and hundreds of thousands of people also fled to safer areas. These flood events continue to repeat from year to year, but always without any solutions [10].

\section{b. Results and Discussion \\ General Concept}

In general, the concept of a house model that is friendly to floods comes from the Sundanese community stage houses (panggung). The stage house is an inspiration to be developed as a house that is friendly to floods. Stage technology was chosen because it has advantages: (1) Good for air circulation, because it can provide a warm feeling at night, and cool during the day; (2) Ponds (empty space) under the floor can be used for water traffic during floods. In general, the house concept can be seen in Figure 4 below.

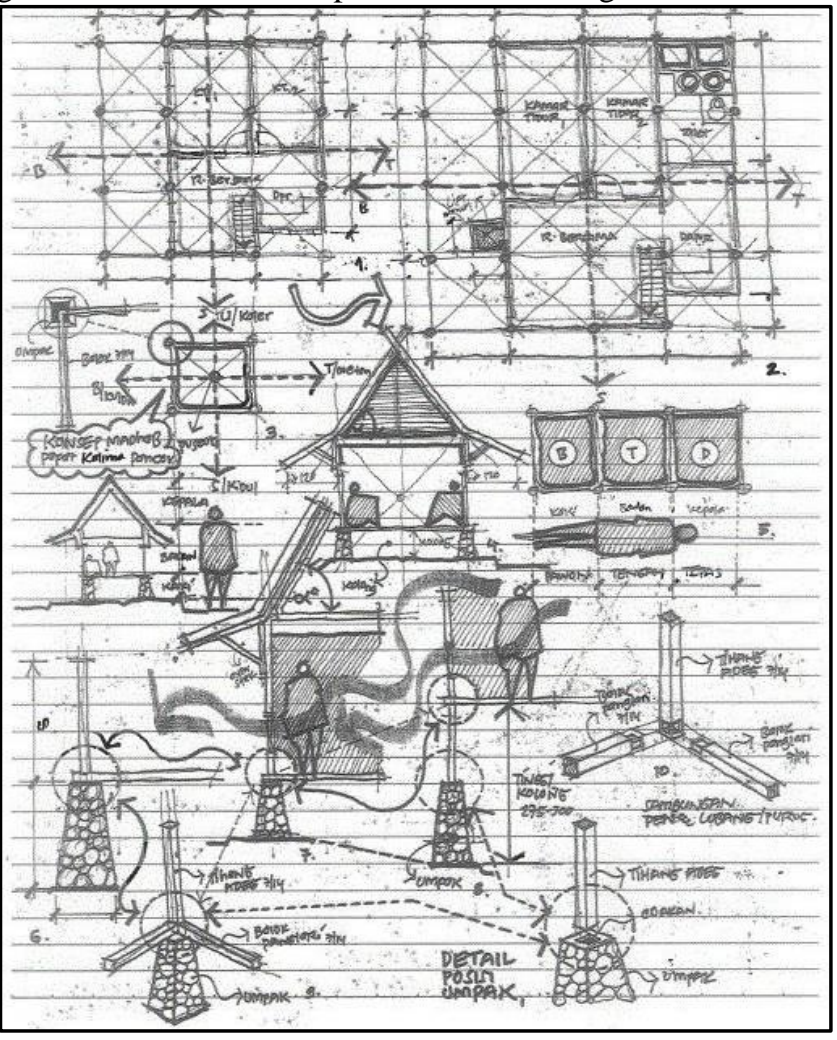

Fig. 4 General concept of flood-friendly house model Source: Nuryanto, et al. [1]

The concept of space in a flood-friendly house is based on a $200 \mathrm{~cm}$ x $200 \mathrm{~cm}$ by grid system. This grid system is very helpful for regulating the location of the foundation (umpak or tatapakan). In addition, the grid system also facilitates the structure of the house, especially the location of the beam. The general concept of the foundation uses a traditional system, which uses stones placed on the surface of the ground. The general concept of house structure is to use beams and wooden columns arranged vertically and horizontally. While the strength of the structure using nails.
With a panggung concept like a traditional Sundanese house, this flood-friendly house has several advantages, including: an excellent air circulation system from the inside to outside, and from the outside into the house through holes in the floor and walls.

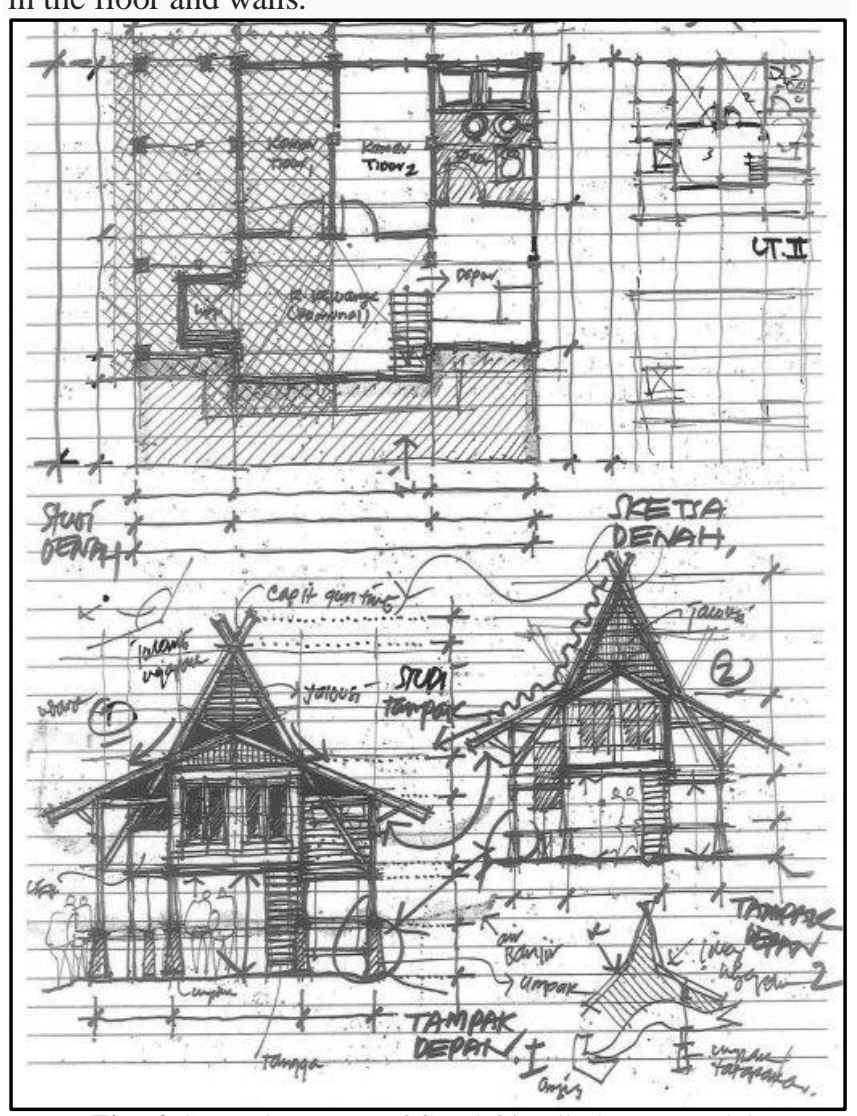

Fig. 4 General concept of flood-friendly house model Source: Nuryanto, et al. [1]

\section{Plan Concept}

The plan concept of a flood-friendly house (drawing 4) is dividd into two main floors, there are: (1) The first floor is the most basic part, not functioned as a living area but as a special empty space to provide space for water flow during the floods. The floor height is $350 \mathrm{~cm}$, with an area for water to flow with a height $275 \mathrm{~cm}$ from the ground. On the first floor there is only one toilet or even no toilet, typically on the second floor, there are the stairs as a vertical circulation for residents of the house. On the first floor, it can also be used as a place for business (shop/service) with a knock-down wall concept or using a partition wall. During the dry season, the first-floor functions as a place of business, even residential, but when the rainy season arrives, all activities are centred to the second floor; (2) The second floor is the centre of occupants' activities, starting from sleeping, cooking and working. The rooms on the second floor include bedroom, toilet, living room, family room, and kitchen. Second-floor height between 350-400 cm with the top (ceiling) can be opened or closed; (3) On the second floor, the ceiling can also function as a mezzanine floor which can be used as a view to the outside of the house. 


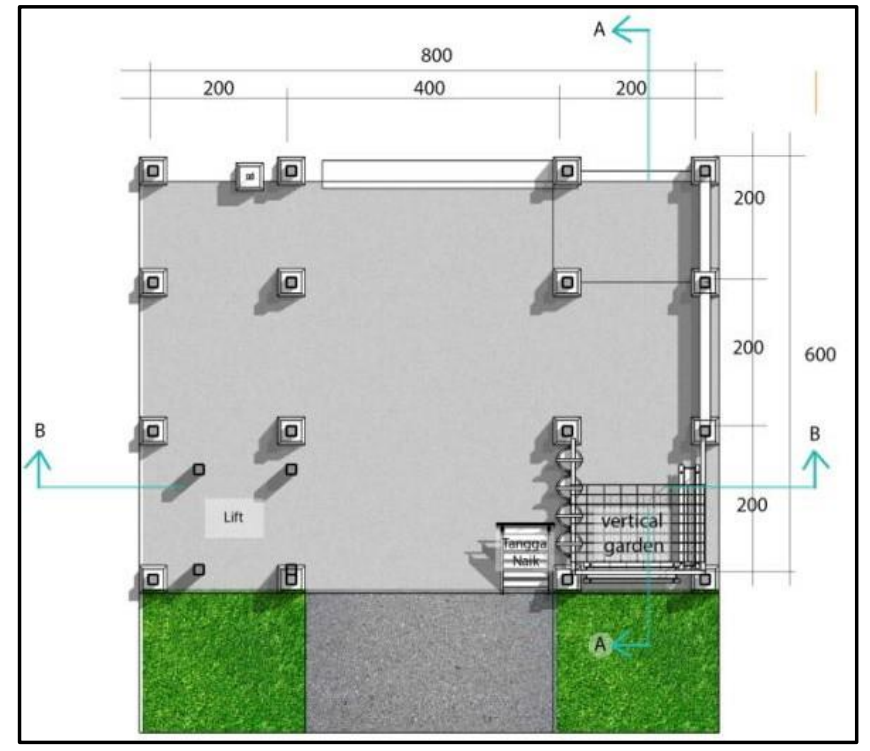

Fig. 4 Floor plan concept of a flood-friendly house Source: Nuryanto, et al. [1]

The plan is related to the placement of umpak or tatapakan foundation points based on the grid or module size of space. Looks related to the appearance of the house, to looks beautiful. The shape of the design roof relates to the roof models uses on the houses on stilts in Kampung Naga which is used as a comparative study for the planning and design of flood-friendly housing. The locals in the location of the study are free to determine the type of roof for their house according to the characteristic of Sundanese architecture.

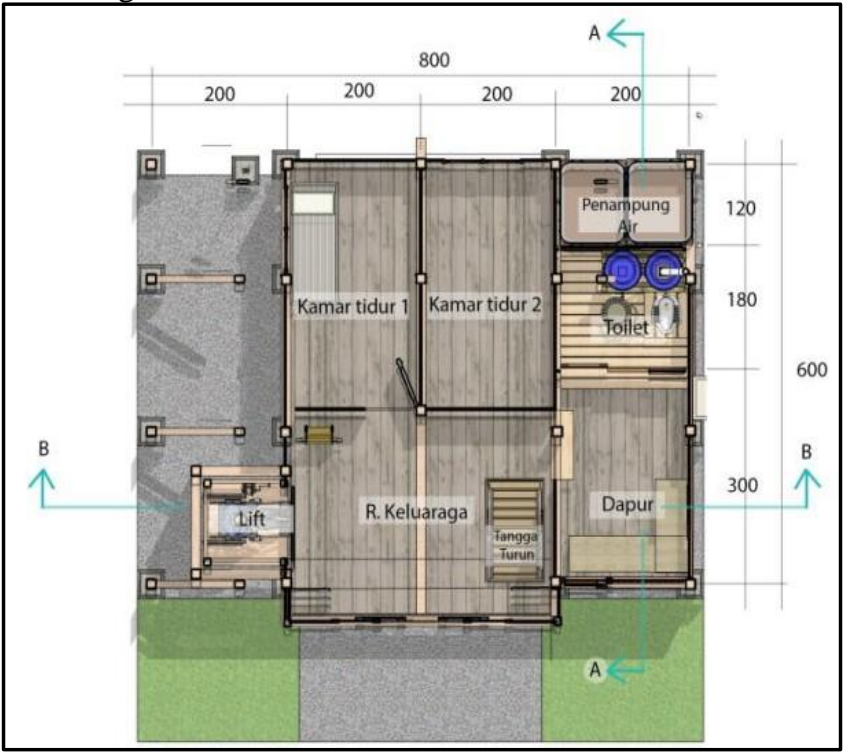

Fig. 5 Floor plan concept of a flood-friendly house Source: Nuryanto, et al. [1]

\section{Facade Concept and Shape of the Roof}

The concept of a flood-friendly house facade adopts the Sundanese architectural design of the house on stilts, especially on roof design. This concept was chosen because the architecture of the house on stilts has a beautiful roof that can not be found in other regional architectures. Typical forms and name terms give a distinctive facade appearance. In addition, the concept of roof design is used because the research location is in the Tatar Sunda area, which makes its architecture as an inspiration for the concept design of a flood-friendly house. The locals of Cieunteung village are free to use roof design for their houses according to the tastes of the residents. In this research, the roof design that is used as an example is julang ngapak (Drawing 5 and 6).

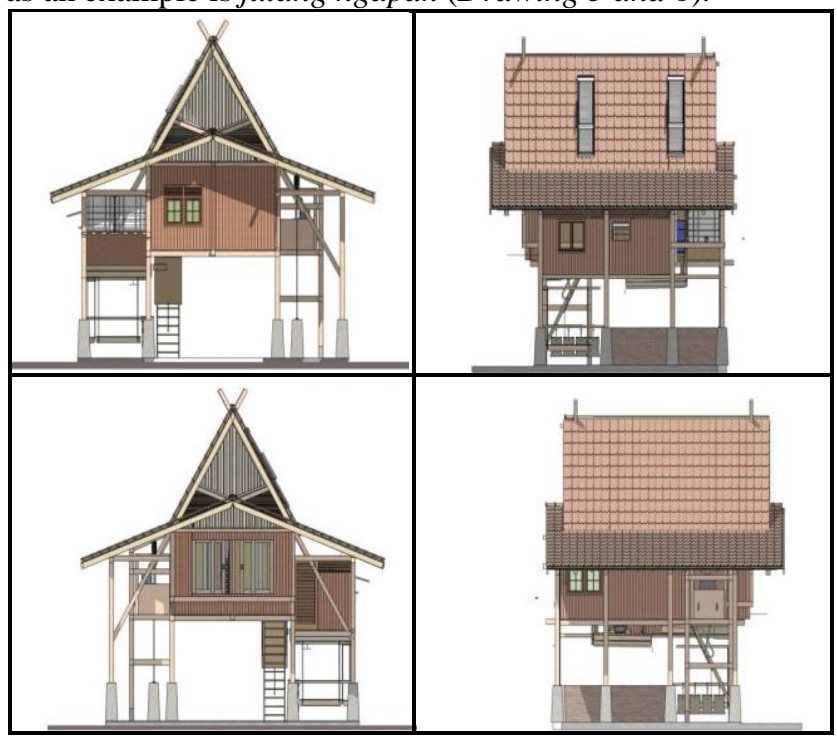

Fig. 6 The concept of a façade of flood-friendly house and the roof design (julang ngapak style/model) Source: Nuryanto, et al. [1]

The facade concept of the house looks very simple, without excessive ornamentation. The Locals of Cieunteung in Babakan Mekarsari village and Jambatan village are free to choose the form of facades for their house according to their taste. These concepts are indirectly given the impression of simplicity in everyday life, to avoid the existence of social inequality among local residents. The majority of local people in both villages live at the level of the middle to lower economy, local residents also build houses according to their economic capabilities.

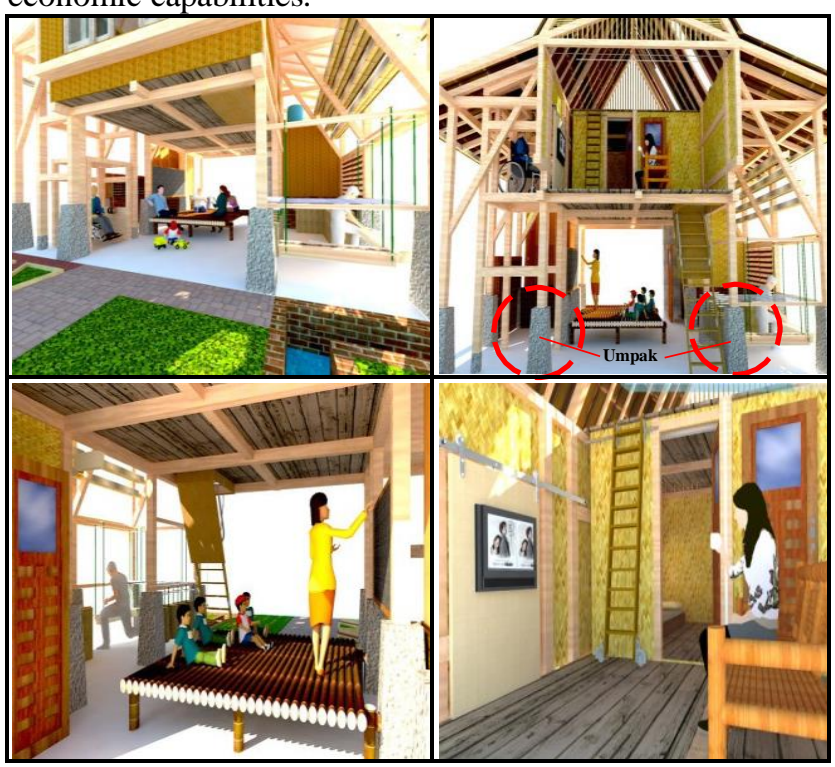

Fig. 7 Illustration of interior and foundation of umpak or tatapakan of a flood-friendly house (prototype/model) Source: Nuryanto, et al. [1] 
The interior space in a flood-friendly house can be divided into two parts, namely: (1) The first floor (below) has space for children's learning, and serves to receive guests or even a small shop (selling activity)); (2) The second floor (above) has a family room, and private rooms (drawing 7).

Construction of foundation can be also use reinforced concrete (drawing 6 and 7) with certain techniques. On top of the foundation, wooden poles or columns are installed, or even from concrete as well as the main structure of the floor support. The columns are connected by the concrete beam at the bottom and the main beam at the top as the floor structure. Column structures are placed according to the module, which is $300 \times 300 \mathrm{~cm}$ with column dimensions of $30 \times 30 \mathrm{~cm}$ (cube shape), or diameter $30-40 \mathrm{~cm}$ (round shape). The column structures use dolken wood or reinforced concrete for the material, the local residents are free to determine it according to their taste and financial ability. In each column, the foot plate foundation will be installed as a base, or put on a umpak foundation (stone pedestal).

The form of structure and construction of houses on stilts which are arranged based on umpak (foundation), pangadeg (cubicle wall), and suhunan (roof) are a whole unity. These three things are the complexity of structure and construction. Includes the process of using building materials, from taking, preserving, processing to using it. All building materials come from nature and the processing is done manually, such as wood and bamboo (drawing 7 and 8). However, it is possible that fabrication materials can be used as additional material. For joint techniques possibly to use nails, bolt nuts, or paseuk (wooden peg) and beungkeut (rope bond) fibres or rattan which are very strong. In this research, for housing materials may use the fabrication materials, or a combination of nature and fabrication materials, for example, the installation of roofs using lightweight tile materials, GRC walls, and lightweight steel roof truss.

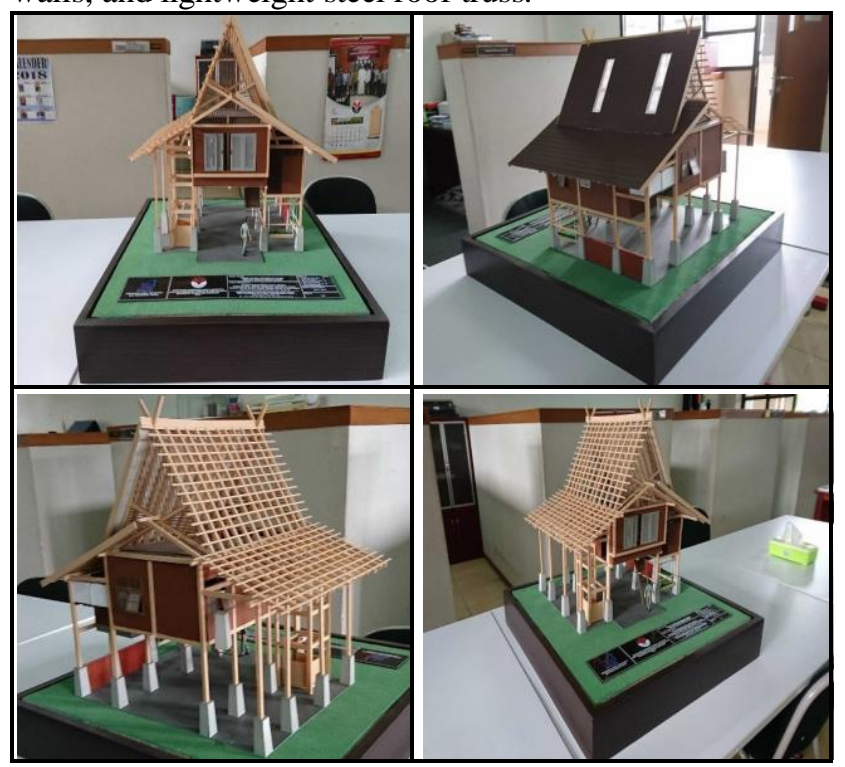

Fig. 8: Mockups or miniature (maket) of a flood-friendly house (prototype/model)

Source: Nuryanto, et al. [1]
Mockup or miniature design of a flood-friendly house in Cieunteung village shows its true form using a scale. This miniature was made to be shown to the flood victims in order that they see the model, so they have an estimate, including costs (real cost estimate). This miniature displays a real form representing the actual form. The appearance of the shape can be seen from various directions, so it is easy to understand (drawing 8). In addition to miniatures, researchers also made mockups of the skeletal structure of the horses using scales. The purpose of mockup horses is to help people understand the strength structure of the roof in a flood-friendly house.

This mockup shows the structure of a flood-friendly house starting from the bottom (foundation) up to the top (roof), so that anyone will easily understand it. Mockup or miniature roof truss friendly houses using wood with a strength system of nails, bolts, muur, and others (drawing 9). In general, the roof system in flood-friendly houses has the same shape. The difference is in certain parts which are installed 'bracing', namely the stiffener and reinforcement system so that the position of the horses does not shift. The distance between the eaves of the house roof is determined based on the space grid system, while the slope angle of the roof is made between $35^{\circ}-45^{\circ}$, so that rain water can flow and fall to the ground quickly.

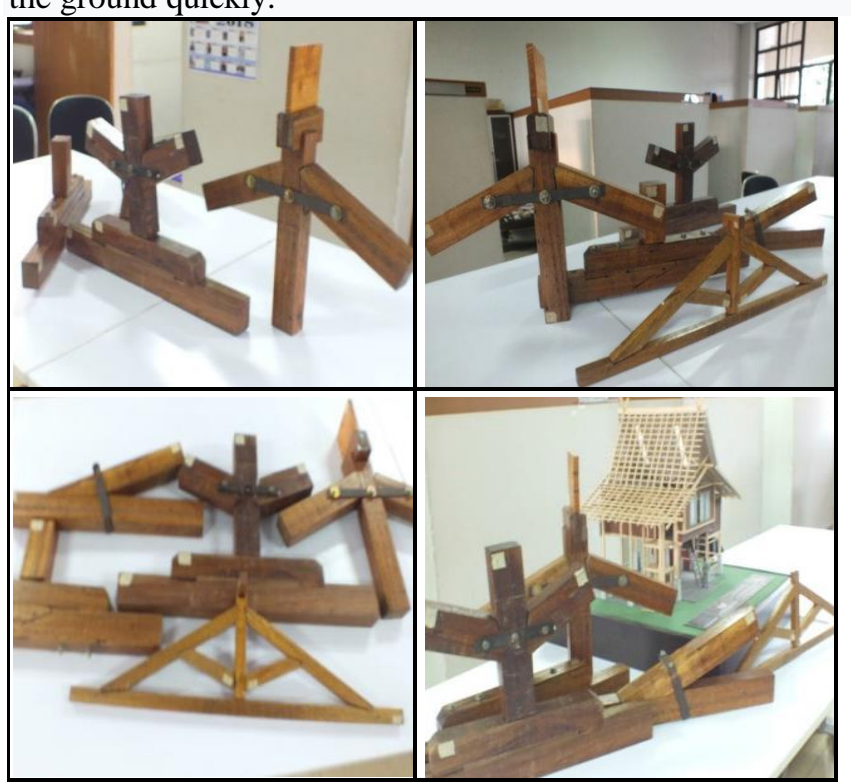

Fig. 9: Mockups or miniature (maket) of structure a flood-friendly house (prototype/model)

Source: Nuryanto, et al. [1]

\section{CONCLUSIONS}

1. The house on stilts in the Sundanese traditional architecture of the Sundanese Society is very relevant to be used as the concept design of the flood-friendly house. The advantages of house on stilts can be seen in four things, there are: (1) the bottom side or pit of the house with a height between $275-300 \mathrm{~cm}$ can be used to anticipate excess water that overflows during a flood, by raising the elevation of the house floor; (2) Umpak 
foundation or tatapakan at the base of the building as the main structure that forms kolong (pit). Umpak foundation can be replaced with dolken wood or concrete columns with a diameter of $\pm 30-40 \mathrm{~cm}$; (3) The structure and construction can uses wood and bamboo or can be replaced by fabrication (truss), or according to the capabilities of the local residents; (4) Typical roof design of Sundanese architecture, such as julang ngapak, jolopong, and capit gunting;

2. The concept of designing a flood-friendly house, three main components include, such as (1) Rectangular floor plan with $300 \mathrm{~cm}$ wall module. The plan consists of two floors, the function of the first floor as a space that is emptied to anticipate the overflow of water during the flood with rising the elevation of the floor by $275-300$ $\mathrm{cm}$. While the residential area is on the second floor which consists of occupied rooms; (2) The house design uses the basic square shape on the facade, while the roof is designed in shape of julang ngapak-capit gunting or perisai in accordance with the character of Sundanese traditional architecture. There are no additional ornaments, the facade of the house appears simply but still unique and attractive; (3) Structural design and construction are included the umpak foundations made from stone, columns of houses made of dolken wood or round reinforced concrete $30-40 \mathrm{~cm}$ in diameter;

3. The concept of planning and designing a flood-friendly house can be proposed to the local government of Bandung Regency as a disaster mitigation tourism area, through several stages, including: (1) Submitted as part of the local government program, especially at the National Disaster Management Agency (BNPBD) of Bandung regency and West Java Provinces regarding of disaster mitigation and early warning system; (2) Make efforts to trace and explore the potential areas in West Java, especially about traditional Sundanese architecture that can be developed as a conceptual approach to disaster-friendly house design, especially flood; (3) Periodic socialization to local residents in prone flood areas about the importance of flood-friendly homes, especially in Cieunteung Village.

\section{RECOMMENDATION}

1. More extensive research needs to be done to determine the potential of traditional Sundanese architecture that can be developed into buildings that are friendly to various disasters, especially in buildings that function as other public facilities, such as offices, education, health, and others. In addition, it is also necessary to conduct in-depth research on the power system structure of houses on stilts that are friendly and safe from flooding;

2. West Java Provincial Government in cooperation with Bandung Regency has created a guidebook to map which areas are prone to (potential) flood hazards that serve as a guide to anticipate them through the design of flood-friendly dwellings;
3. Creating a special curriculum on disaster mitigation at the Elementary School (SD) level, SLTP, and SLTA, as an effort to prevent early and instill early awareness about disaster anticipation. In addition, students are also invited to learn directly through visits to areas prone to flooding and comparative studies in Sundanese traditional villages to find out their own local wisdom.

\section{ACKNOWLEDGEMENTS}

This research is the 2018 Superior Funding Research Scheme (PDUPT) funded by the Republic of Indonesia Ministry of Research, Technology and Higher Education (Kemenristekdikti RI). The research team expressed their gratitude to all those who contributed to this research. To the honor parties: (1) Ministry of Research, Technology and Higher Education Republic of Indonesia for PDUPT research opportunities; (2) Rector, vice rector and all staff at the Universitas Pendidikan Indonesia (UPI); (3) Institute of Research and Community Services (LPPM) Universitas Pendidikan Indonesia; (4) Dean, vice dean, and all staff at the FPTK-UPI; (5) Head of Department of Architecture, Prodi and all staff DPTA-FPTK UPI; (6) Governors, Regents, and Sub-District Heads; (7) Head of BAPPEDA, BNPBD, and BBWSC West Java Province; (8) Chairperson of RW, RT, community leaders, youth leaders, and communities in the research location; (9) Students participating in the Final Project Architecture and Skripsi: Maulana Akbar Harahap, Indra Setiawan, Ridwan, Raden Luthfi, Ishak Budiman, and Agung.

\section{REFERENCES}

[1] Nuryanto, R. I. Surasetja, and D. Ahdiat, "Kajian Pembangunan Sosial-Budaya: Kearifan Lokal Rumah Panggung Arsitektur Sunda sebagai Model Desain Rumah Ramah Banjir di Jawa Barat (Studi Kasus: Kampung Cieunteung-Baleendah, Kabupaten Bandung)," Departemen Pendidikan Teknik Arsitektur, FPTK Universitas Pendidikan Indonesia, Bandung2019, Available: https://lppm.upi.edu/, Accessed on: 18 Mei 2019.

[2] Suripin, Sistem Drainase Perkotaan yang Berkelanjutan, Pertama ed. Yogyakarta: Andi Offset, Yogyakarta, 2004.

[3] W. J. S. Poerwadarminta, "Kamus Besar Bahasa Indonesia," in $K B B I$, Edisi Pertama ed. Jakarta: Balai Pustaka, Jakarta, 1990.

[4] R. J. Kodoatie and Sugiyanto, Banjir dan Permasalahannya, Edisi Pertama ed. Semarang: Pustaka Pelajar, SemarangJawa Tengah, 2001.

[5] E. S. Ekadjati, Kebudayaan Sunda (Suatu Pendekatan Sejarah), Edisi Pertama ed. Jakarta: Pustaka Jaya, Jakarta, 1995.

[6] S. Danumihardja, "Model Pengembangan Desa: Sebuah Kajian Sosiologi Arsitektur Perdesaan di Jawa Barat," Tesis Magister, Magister Arsitektur FTSP Institut Teknologi Bandung (ITB), Institut Teknologi Bandung (ITB), tidak untuk diterbitkan, 1987.

[7] K. Adimihardja and P. Salura, A. Holid, Ed. Arsitektur dalam Bingkai Kebudayaan, Edisi Pertama ed. Bandung: FORIS Communication, Bandung, 2004. 
International Journal of Engineering and Emerging Technology Vol. 4 No. 2 July - December 2019

[8] A. S. Suhamihardja, Organisasi dan Struktur Sosial Masyarakat Sunda dan Agama, Kepercayaan, dan Sistem Pengetahuan dalam Masyarakat Sunda dan Kebudayaannya, Edisi Pertama ed. Bandung: Girimukti Pasaka, Bandung, Jawa Barat, 1984.

[9] J. M. Echols and H. Shadily, "Kamus Indonesia-Inggris," in Kamus Indonesia-Inggris (An Indonesian-English Dictionary), Edisi Ketiga ed. Jakarta: PT. Gramedia Pustaka Utama, Jakarta, 2014.

[10] B. N. P. B. (BNPB), "Indeks Resiko Bencana di Indonesia," Badan Nasional Penanggulangan Bencana (BNPB), Jakarta, Laporan Tahunan 2013, Available: https://bnpb.go.id/, Accessed on: 18 April 2019. 